\title{
Pittosporum baudouinii
}

\author{
Assessment by: Gemmill, C., Veillon, J.-M., Amice, R., Cazé, H., Dumontet, V., \\ Fleurot, D., Garnier, D., Gâteblé, G. \& Maggia, L.
}

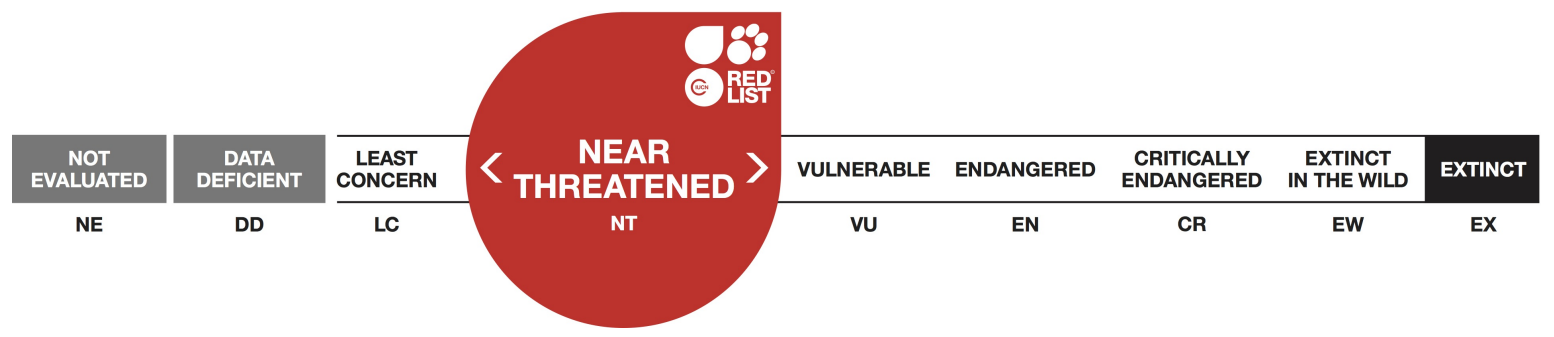

View on www.iucnredlist.org

Citation: Gemmill, C., Veillon, J.-M., Amice, R., Cazé, H., Dumontet, V., Fleurot, D., Garnier, D., Gâteblé, G. \& Maggia, L. 2017. Pittosporum baudouinii. The IUCN Red List of Threatened Species 2017: e.T82946542A82951752. http://dx.doi.org/10.2305/IUCN.UK.20173.RLTS.T82946542A82951752.en

Copyright: (C) 2017 International Union for Conservation of Nature and Natural Resources

Reproduction of this publication for educational or other non-commercial purposes is authorized without prior written permission from the copyright holder provided the source is fully acknowledged.

Reproduction of this publication for resale, reposting or other commercial purposes is prohibited without prior written permission from the copyright holder. For further details see Terms of Use.

The IUCN Red List of Threatened Species ${ }^{T M}$ is produced and managed by the IUCN Global Species Programme, the IUCN Species Survival Commission (SSC) and The IUCN Red List Partnership. The IUCN Red List Partners are: Arizona State University; BirdLife International; Botanic Gardens Conservation International; Conservation International; NatureServe; Royal Botanic Gardens, Kew; Sapienza University of Rome; Texas A\&M University; and Zoological Society of London. 


\section{Taxonomy}

\begin{tabular}{|c|c|c|c|c|}
\hline Kingdom & Phylum & Class & Order & Family \\
\hline Plantae & Tracheophyta & Magnoliopsida & Rosales & Pittosporaceae \\
\hline
\end{tabular}

Taxon Name: Pittosporum baudouinii Brongn. \& Gris

\section{Taxonomic Source(s):}

Tirel, Ch. and Veillon, J.-M. 2002. Flore de la Nouvelle-Calédonie, tome 24. Pittosporaceae. Museum d'Histoire Naturelle, Paris.

\section{Assessment Information}

Red List Category \& Criteria: $\quad$ Near Threatened ver 3.1

Year Published: 2017

Date Assessed: July 23, 2015

\section{Justification:}

Pittosporum baudouinii is a shrub of New Caledonia, observed in the south of the main island, Grande Terre, from Dumbéa valley to Dothio. This species occurs in shrubland and forest edges on eroded soil or colluvium derived from ultramafic rocks at an altitudinal range 100-800 $\mathrm{m}$ asl. Its area of occupancy and extent of occurrence are equal to 56 and $855 \mathrm{~km}^{2}$ respectively. With more than 10 locations impacted by mining activities, bushfires and Rusa Deer (Rusa timorensis), P. baudouinii qualifies for listing as Near Threatened (NT) close to (VU) B1ab(ii,iii,v)+2ab(ii,iii,v).

\section{Geographic Range}

\section{Range Description:}

Pittopsorum baudouinii is an endemic shrub of New Caledonia, found in the south of the main island, Grande Terre, from Dumbéa valley to Dothio.

\section{Country Occurrence:}

Native: New Caledonia 


\section{Distribution Map}

\section{Pittosporum baudouinii}

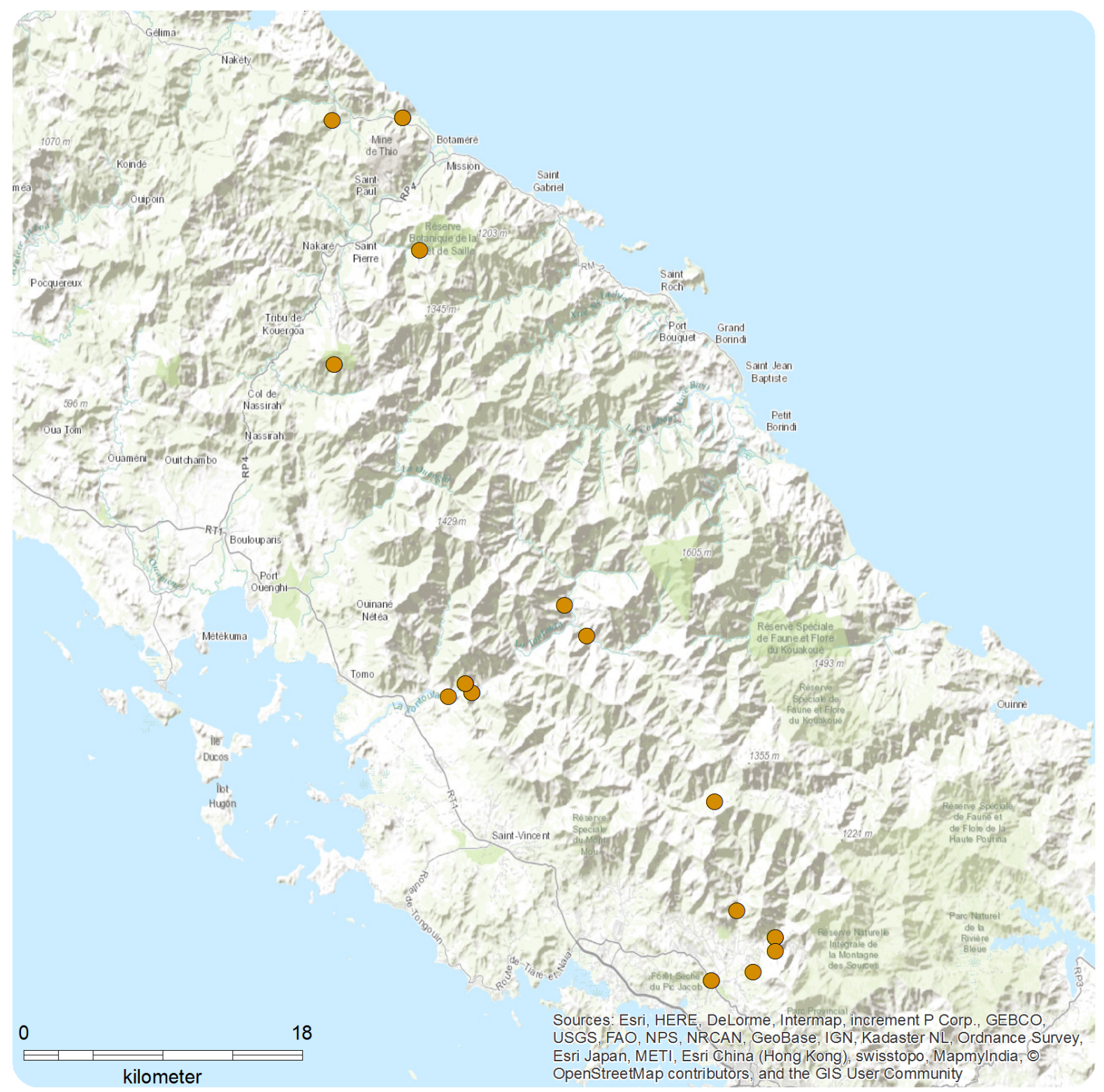

Range

Extant (resident)
Compiled by:

IUCN SSC New Caledonia Plants RLA

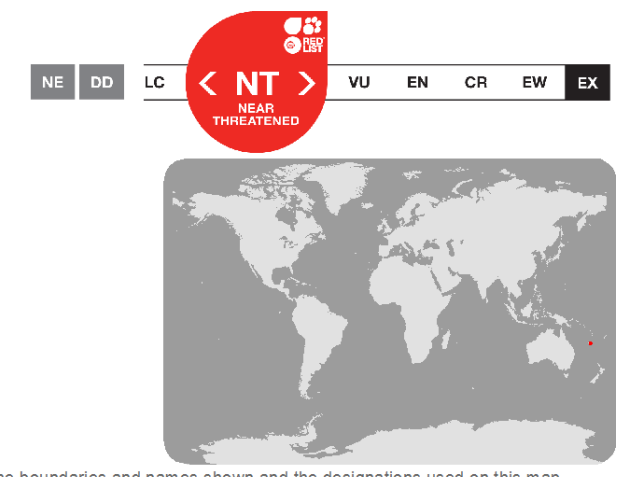

- 


\section{Population}

Population size is unknown. Field observations indicate that it occurs mostly as isolated plants.

Current Population Trend: Stable

\section{Habitat and Ecology (see Appendix for additional information)}

Pittopsorum baudouinii occurs in shrubland and on forest edges in eroded soil or colluvium derived from ultramafic rocks at an altitudinal range $100-800 \mathrm{~m}$ asl.

Systems: Terrestrial

\section{Threats (see Appendix for additional information)}

In contrast to subpopulations on the massif du Taom for which mining activities were a past threat, subpopulations on Vulcain, Ningua and Toutouta are under threat due to mining activities. As Pittopsorum baudouinii is most frequently collected on massif slopes, this species could be less threatened than other species located on the summit and directly impacted by mining activities. Water stress due to climate change could also affect populations of $P$. baudouinii. Rusa Deer, a major invasive animal species in New Caledonia, constitutes a potential threat to regeneration of populations because they graze the seedlings.

\section{Conservation Actions (see Appendix for additional information)}

Pittopsorum baudouinii is currently not protected by legislation. Nevertheless, this species occurs in two protected areas: the réserve naturelle du Pic Ningua and the réserve naturelle de la Haute Dumbéa. The côte oubliée and the area of Thio N'Deu should be surveyed.

\section{Credits}

Assessor(s): $\quad$ Gemmill, C., Veillon, J.-M., Amice, R., Cazé, H., Dumontet, V., Fleurot, D., Garnier, D., Gâteblé, G. \& Maggia, L.

Reviewer(s): $\quad$ Tanguy, V.

Facilitators(s) and Chanfreau, S.

Compiler(s): 


\section{Bibliography}

Endemia.nc. 2016. Faune et Flore de Nouvelle-Calédonie. Available at: http://www.endemia.nc.

IUCN. 2017. The IUCN Red List of Threatened Species. Version 2017-3. Available at: www.iucnredlist.org. (Accessed: 7 December 2017).

L'Huillier, L., Jaffré, T. and Wulff, A. 2010. Mines et Environnement en Nouvelle-Calédonie: les milieux sur substrats ultramafiques et leur restauration. IAC, Nouméa.

Tirel, Ch. and Veillon, J.-M. 2002. Flore de la Nouvelle-Calédonie, tome 24. Pittosporaceae. Museum d'Histoire Naturelle, Paris.

\section{Citation}

Gemmill, C., Veillon, J.-M., Amice, R., Cazé, H., Dumontet, V., Fleurot, D., Garnier, D., Gâteblé, G. \& Maggia, L. 2017. Pittosporum baudouinii. The IUCN Red List of Threatened Species 2017: e.T82946542A82951752. http://dx.doi.org/10.2305/IUCN.UK.2017-3.RLTS.T82946542A82951752.en

\section{Disclaimer}

To make use of this information, please check the Terms of Use.

\section{External Resources}

For Images and External Links to Additional Information, please see the Red List website. 


\section{Appendix}

\section{Habitats}

(http://www.iucnredlist.org/technical-documents/classification-schemes)

\begin{tabular}{|c|c|c|c|}
\hline Habitat & Season & Suitability & $\begin{array}{l}\text { Major } \\
\text { Importance? }\end{array}$ \\
\hline 1. Forest -> 1.6. Forest - Subtropical/Tropical Moist Lowland & - & Suitable & - \\
\hline 3. Shrubland -> 3.5. Shrubland - Subtropical/Tropical Dry & - & Suitable & - \\
\hline
\end{tabular}

\section{Threats}

(http://www.iucnredlist.org/technical-documents/classification-schemes)

\begin{tabular}{|c|c|c|c|c|}
\hline Threat & Timing & Scope & Severity & Impact Score \\
\hline \multirow{2}{*}{$\begin{array}{l}\text { 11. Climate change \& severe weather }->11.2 \text {. } \\
\text { Droughts }\end{array}$} & Ongoing & - & - & - \\
\hline & Stresses: & \multicolumn{3}{|c|}{$\begin{array}{l}\text { 1. Ecosystem stresses }->1.2 \text {. Ecosystem degradation } \\
\text { 2. Species Stresses }->2.1 \text {. Species mortality } \\
\text { 2. Species Stresses }->2.3 \text {. Indirect species effects }-> \\
\text { 2.3.7. Reduced reproductive success }\end{array}$} \\
\hline \multirow{2}{*}{$\begin{array}{l}\text { 3. Energy production \& mining }->3.2 \text {. Mining \& } \\
\text { quarrying }\end{array}$} & Ongoing & - & - & - \\
\hline & Stresses: & \multicolumn{3}{|c|}{$\begin{array}{l}\text { 1. Ecosystem stresses }->1.1 \text {. Ecosystem conversion } \\
\text { 1. Ecosystem stresses }->1.2 \text {. Ecosystem degradation }\end{array}$} \\
\hline \multirow[t]{2}{*}{$\begin{array}{l}\text { 8. Invasive and other problematic species, genes } \& \\
\text { diseases }->8.1 \text {. Invasive non-native/alien } \\
\text { species/diseases }->8.1 .2 \text {. Named species (Rusa } \\
\text { timorensis) }\end{array}$} & Ongoing & - & - & - \\
\hline & Stresses: & \multicolumn{3}{|c|}{$\begin{array}{l}\text { 2. Species Stresses }->2.2 \text {. Species disturbance } \\
\text { 2. Species Stresses }->2.3 \text {. Indirect species effects }-> \\
\text { 2.3.7. Reduced reproductive success }\end{array}$} \\
\hline
\end{tabular}

\section{Conservation Actions in Place}

(http://www.iucnredlist.org/technical-documents/classification-schemes)

\begin{tabular}{|l|}
\hline Conservation Actions in Place \\
\hline In-Place Land/Water Protection and Management \\
\hline Occur in at least one PA: Yes \\
\hline Invasive species control or prevention: No \\
\hline In-Place Species Management \\
\hline Successfully reintroduced or introduced beningly: No \\
\hline Subject to ex-situ conservation: No \\
\hline
\end{tabular}




\section{Research Needed}

(http://www.iucnredlist.org/technical-documents/classification-schemes)

\section{Research Needed}

1. Research $->1.2$. Population size, distribution \& trends

\section{Additional Data Fields}

\begin{tabular}{|l|}
\hline Distribution \\
\hline Estimated area of occupancy (AOO) ( $\left.\mathrm{km}^{2}\right): 56$ \\
\hline Continuing decline in area of occupancy (AOO): Yes \\
\hline Extreme fluctuations in area of occupancy (AOO): No \\
\hline Estimated extent of occurrence (EOO) ( $\mathrm{km}^{2}$ ): 855 \\
\hline Continuing decline in extent of occurrence (EOO): No \\
\hline Extreme fluctuations in extent of occurrence (EOO): No \\
\hline Number of Locations: $1-20$ \\
\hline Continuing decline in number of locations: No \\
\hline Extreme fluctuations in the number of locations: No \\
\hline Lower elevation limit (m): 10 \\
\hline Upper elevation limit (m): 800 \\
\hline Population \\
\hline Continuing decline of mature individuals: Yes \\
\hline Extreme fluctuations: No \\
\hline Population severely fragmented: No \\
\hline No. of subpopulations: 9 \\
\hline Extreme fluctuations in subpopulations: No \\
\hline Habitats and Ecology \\
\hline Continuing decline in area, extent and/or quality of habitat: Yes \\
\hline Generation Length (years): 0 \\
\hline
\end{tabular}




\section{The IUCN Red List Partnership}

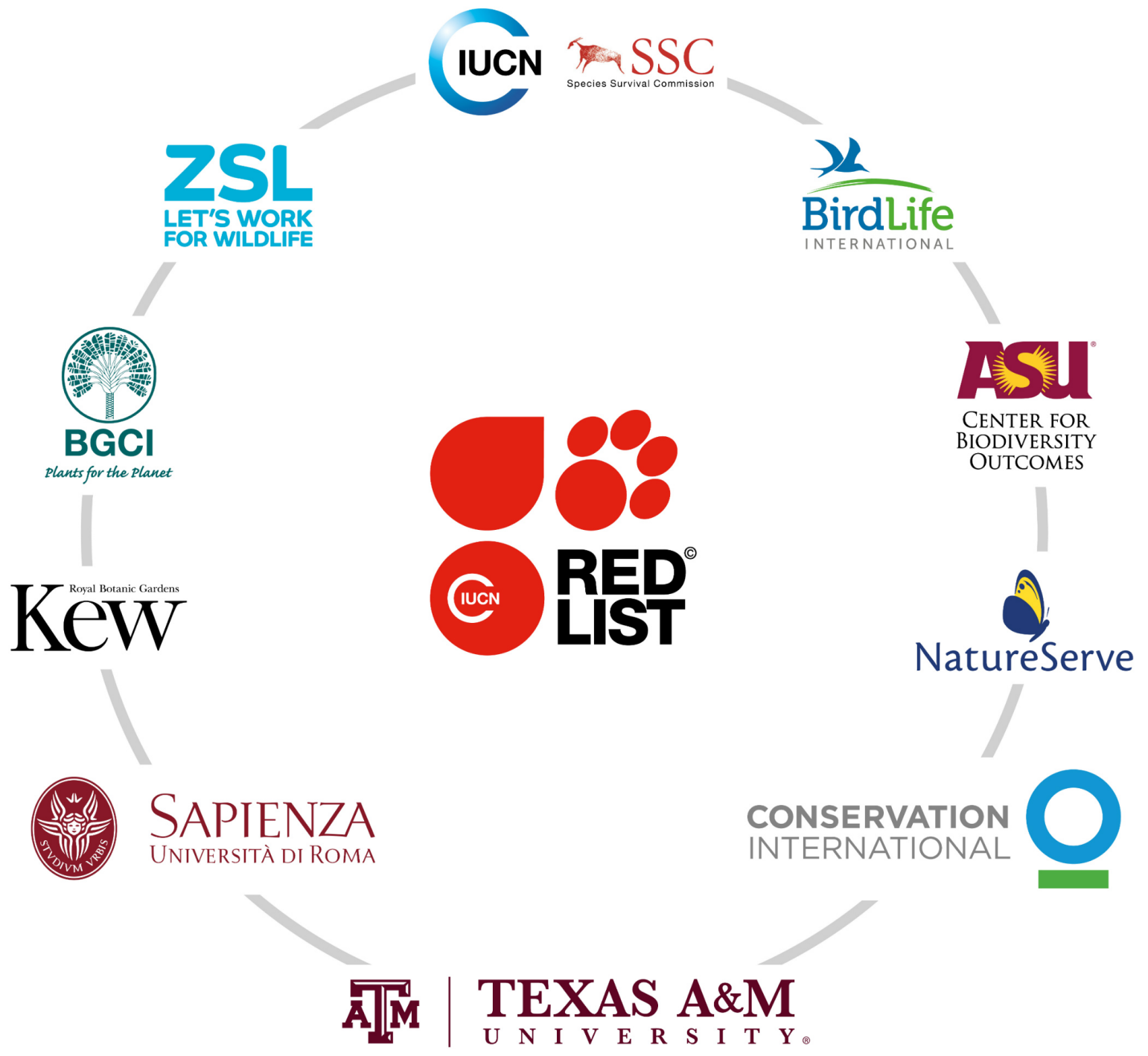

The IUCN Red List of Threatened Species ${ }^{\mathrm{TM}}$ is produced and managed by the IUCN Global Species Programme, the IUCN Species Survival Commission (SSC) and The IUCN Red List Partnership.

The IUCN Red List Partners are: Arizona State University; BirdLife International; Botanic Gardens Conservation International; Conservation International; NatureServe; Royal Botanic Gardens, Kew; Sapienza University of Rome; Texas A\&M University; and Zoological Society of London. 